\title{
Relation between Weight at Birth and 21, 56, and 154. Days of Age In Pigs
}

\author{
Ismael Carlo and Carlos L. Arcelay ${ }^{1}$
}

\section{INTRODUCTION}

The live weight that an animal attains at each of the different stages of its life is supposed to be of great importance as an index of its healthiness and future behavior. This is more so in the case of animals of economic importance for the farmer, such as swine. There are at least four different periods in the life of the pigs in which the live weight plays an important role for the producer. These periods are at birth, at 21 days, at weaning, and at 154 days of age. It has been said that each successive weight period has a direct influence on the next one. It is the purpose of this study to determine whether such was the case with the pigs of the line developed by the Agricultural Experiment Station, Mayagüez Campus, of the University of Puerto Rico.

\section{PROCEDURE}

The study covered six farrowings seasons of the $3 / 4$ Duroc $\times 1 / 4$ English Large Black Landrace line of pigs which extended from the fall of 1961 to the fall of 1965. The data used in this study were those obtained on a total of 41 boars, 86 barrows, and 138 gilts. The pigs included were those completing the age of 154 days under a growing-finishing experiment. In that way the four different weight periods were available in each case.

The pigs were divided by sexes, and the weight for the gilts, the barrows, and the boars were recorded for each particular period. The weights considered were at birth, at 21 days, at weaning, and at 154 days of age. The correlations were worked out for each sex. An analysis of variance was made to find out if there was significant difference in each of the weight periods due to sex.

\section{RESULTS AND DISCUSSION}

The weights of all the pigs at the different subsequent weight periods by sexes are shown in table 1.

In boars there were highly significant positive correlations between birth-weight and the weight at 21 days of age; between the weight at 21 days and at weaning; and between the weight at weaning and at 154 days of age.

\footnotetext{
1 Animal Husbandman and Professor, Agricultural Experiment Station and College of Agriculture and Mechanical Arts, and Professor and Animal Husbandman, College of Agriculture and Mechanical Arts and Agricultural Experiment Station, Mayagüez Campus, University of Puerto Rico, Mayagüez and Río Piedras, P.R.
} 
No significant correlations were found among the other weight periods.

It is worthwhile to notice that all the significant correlations were found when the comparisons were made between two successive weight periods. The highest correlation was obtained between weaning weight and that of 154 days of age $(+0.65)$. This was followed by the correlation between birth-weight and 21-day weight (+0.54). The smallest significant correlation was obtained between the weight at 21 days and that at weaning time $(+0.34)$.

TABLE 1.-A verage weight (pounds) of pigs of the $3 / 4$ Duroc $\times 1 / 4$ English Large Black Landrace at birlh, 21 days, weaning, and 154 days, by sexes

\begin{tabular}{l|r|r|r}
\hline Weight period & \multicolumn{1}{|c|}{ Boars } & Barrows & \multicolumn{1}{|c}{ Gilts } \\
Birth & 3.04 & 2.95 & 2.80 \\
21 days & 11.48 & 11.10 & 10.71 \\
Weaning & 34.92 & 34.26 & 35.28 \\
154 days & 204.58 & 198.90 & 191.73 \\
\hline
\end{tabular}

The correlation coefficients are shown in the following tabulation:

Weight period

Birth and 21-day weights

Birth and weaning weights

Birth and 154-day weights

21-day and weaning weights

21-day and 154-day weights

Weaning and 154-day weights
Correlation coefficient

$0.54^{1}$

.15 N.S.

.21 N.S.

$.34^{2}$

.18 N.S.

$.65^{1}$

${ }^{1}$ Significant at 1 percent.

2 Significant at 5 percent.

Among the barrows, as among the boars, there were positive significant correlations between successive weight periods, but in addition to that, there were also positive significant correlations between any two weight periods.

The highest correlations were found in subsequent weight periods. The correlation coefficient between birth weight and that at 21 days of age was +0.62 . The one between the weight at 21 days and at weaning was +0.71 ; while that between weaning weight and that at 154 days was +0.60 . This last correlation coefficient was close to that obtained for the boars during these two subsequent weight periods.

All the correlation coefficients are shown in the following tabulation: 


\begin{tabular}{lc}
\multicolumn{1}{c}{ Weight periods } & Correlation coefficients \\
Birth and 21-day weights & 0.62 \\
Birth and weaning weights & .55 \\
Birth and 154-day weights & .41 \\
21-day and weaning weights & .71 \\
21-day and 154-day weights & .41 \\
Weaning and 154-day weights & .60
\end{tabular}

${ }^{1}$ All significant at 1 percent.

In gilts, as was found in the barrows, there were highly significant positive correlations between any two weight periods compared, regardless of whether they were successive or not. The correlation coefficients between weight at birth and that at 21 days was +0.52 ; that between 21 -day weight

TABLE 2.-Analysis of variance for the birth-weight of the boars, barrows, and gilts

\begin{tabular}{l|r|r|r|r}
\hline Source of variation & D/F & S.S. & M.S. & F \\
\cline { 2 - 4 } Sex & 2 & 2.23 & 1.15 & $3.83^{1}$ \\
Error & 262 & 78.44 & .30 & \\
\cline { 2 - 4 } Total & 264 & 80.67 & & \\
\hline
\end{tabular}

${ }^{1}$ Significant at 5-percent level

$\begin{array}{lccc} & \text { Boars } & \text { Barrows } & \text { Gilts } \\ \text { Duncan Multiple Test at 5-percent level } & 3.04 & 2.95 & 2.80\end{array}$

and weaning was +0.68 , and that between weight at weaning and 154-day weight was +0.61. Again, this last correlation coefficient was similar to the one obtained for that same weight period in the boars and in the barrows.

The tabulation that follows shows the correlation coefficients in the case of the gilts:

\section{Weight periods}

Birth and 21-day weights

Birth and weaning weights

Birth and 154-day weights

21-day and weaning weights

21-day and 154-day weights

Weaning and 154-day weights
Correlation coefficients

0.52

.53

.40

.68

.26

.61

1 All significant at 1 percent.

The analysis of variance for differences in the birth-weight attributable to 
sex is presented in table 2 and it shows that there was significant difference attributable to this factor.

The Duncan multiple range test ${ }^{2}$ showed that there was no significant difference between the birth weight of the boars or the barrows, but that both were significantly different when compared with the birth weight of the gilts. The highest birth weight was that of the boars, followed by the

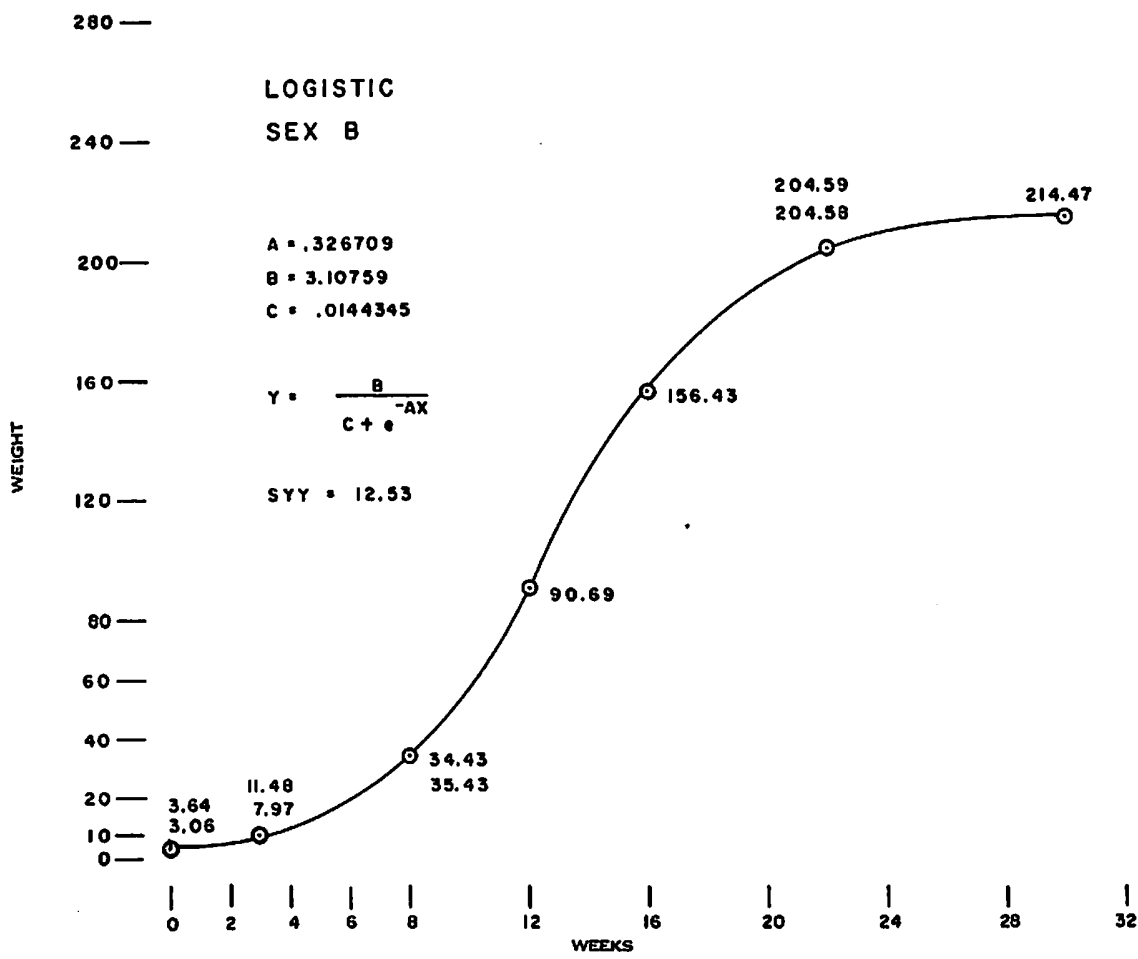

Frg. 1.-Boar's growth curve.

barrows, and finally the gilts. It should be stated here that, although there was no significant difference among the boars or the barrows, pigs left as boars were selected on the basis of weights, taking the heavier ones for the purpose under practical conditions.

Further analysis of the same data was made using the logistic equation. Figures 1, 2, and 3 show the curve for the boars, the barrows, and the gilts, respectively. The correlation coefficients for the boars was +0.5149 , for the barrows was +0.5245 , and that for the gilts +0.7866 . All of them are

2 Steel, Robert, G. D., and Torrie, James H., Principles and Procedures of Statistics, McGraw-Hill Book Co., New York, N.Y., 1960. 
significant at the 1-percent level of distribution. The growth curve obtained in each case rather well follows the actual growth rate of the animals.

In tables 3 and 4 are presented the analysis of variance for the differences in weights at 21 days and the weaning weights due to sex. Neither of these two analyses showed significant differences attributable to sex.

The analysis of variance for the differences in weight at 154 days due to sex are shown in table 5 . There was a highly significant difference in this

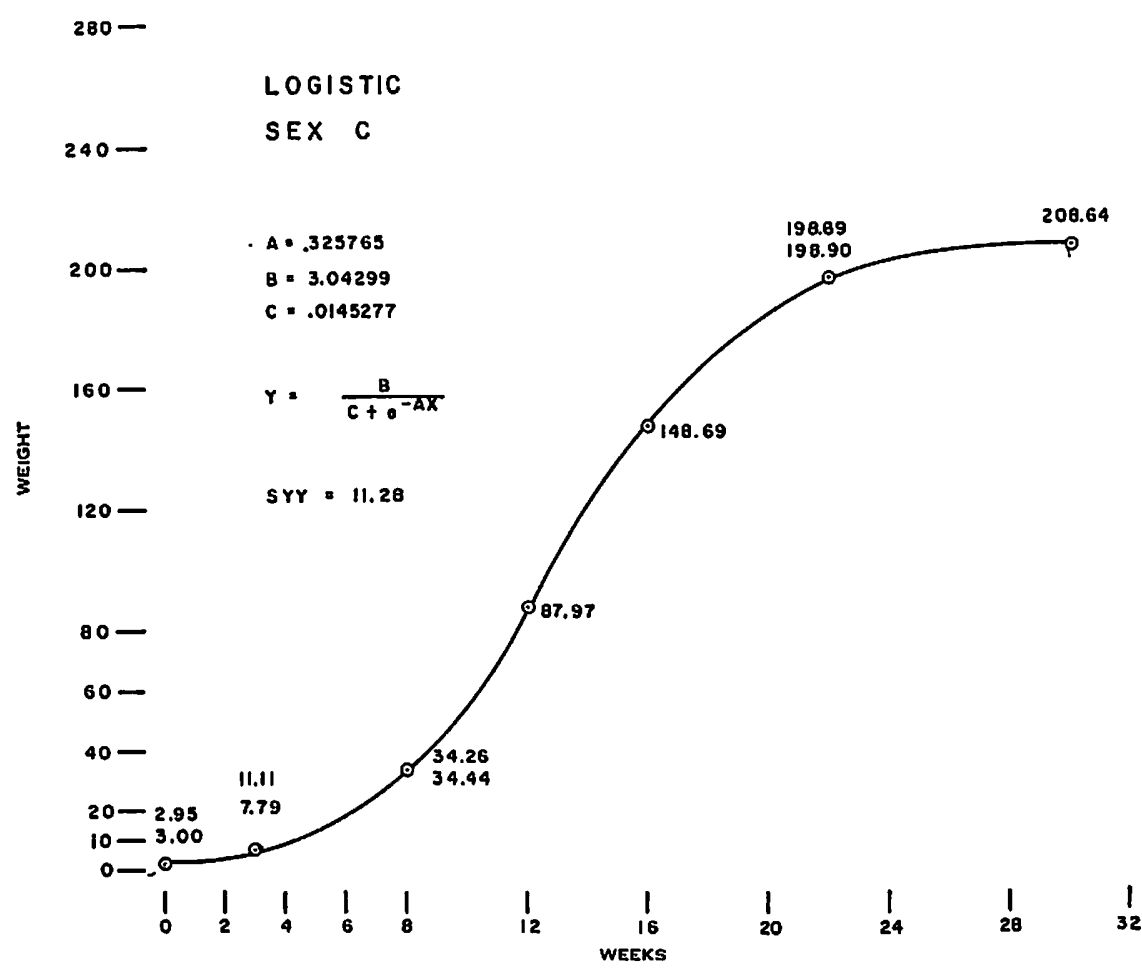

Fig. 2.-Barrow's growth curve.

case. The Duncan multiple range test showed that there was no significant difference between the boars and the barrows, nor between the barrows and the gilts when the comparison was made at the 1-percent level, but there was between the weights of the boars and the gilts. When the comparison was made at the 5-percent level, there was no significant difference between the boars' and the barrows' weights, but both of them were significantly different from the weights of the gilts.

\section{CONCLUSIONS}

The highly significant and positive correlation coefficients obtained in this study tend to show that each weight period has a direct positive 
$280-$

LOGISTIC
$240-\quad$ SEXF

$200-\quad A=.33866$

c. .014510

$r=\frac{B}{c+i^{-A X}}$

농
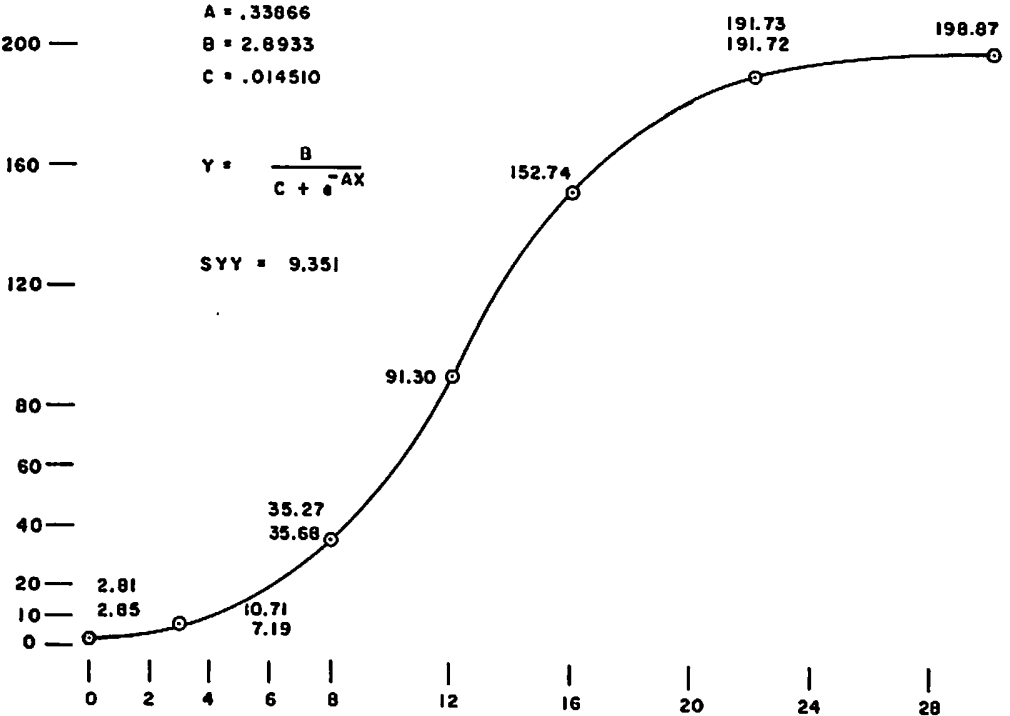

Fra. 3.-Gilt's growth curve.

TABLE 3.-Analysis of variance for the 21 -day weight of boars, barrows, and gills

\begin{tabular}{|c|c|c|c|c|}
\hline Source of variation & $\mathrm{D} / \mathrm{F}$ & s.s. & M.S. & $\mathbf{F}$ \\
\hline $\begin{array}{l}\text { Sex } \\
\text { Error }\end{array}$ & $\begin{array}{r}2 \\
262\end{array}$ & $\begin{array}{r}21.22 \\
1,068.76\end{array}$ & $\begin{array}{r}10.61 \\
4.08\end{array}$ & $2.60^{1}$ \\
\hline Total & 264 & $1,089.98$ & & \\
\hline
\end{tabular}

${ }^{1}$ Not significant.

TABLE 4.-Analysis of variance for weaning weight of boars, barrows, and gills

\begin{tabular}{l|r|r|r|r}
\hline Source of variation & D/F & S.S. & M.S. & F \\
\cline { 1 - 4 } Sex & 2 & $\begin{array}{r}54.50 \\
\text { Error }\end{array}$ & 27.25 & $0.61^{1}$ \\
& 262 & $11,631.19$ & 44.39 & \\
\cline { 2 - 4 } Total & 264 & $11,685.69$ & & \\
\hline
\end{tabular}

: Not significant. 
influence in its succeeding one. According to these figures, the future weights of the pigs at a certain period can be estimated with a certain degree of accuracy, if the weight of the preceding period is known.

Of particular importance for the breeding work at this Station is the fact that a positive highly significant correlation coefficient of over +0.60 was always found for sex between the weaning weight and that at 154 days of age. This could help shorten the time the pigs have to be kept, since, instead of carrying them to 154 days, selection could be made at weaning time (56 days).

The logistic equation applied to the same data also confirmed the above statement.

TABLE 5.-Analysis of variance for 154-day weight for boars, barrows, and gilts

\begin{tabular}{l|r|r|r|c}
\hline Source of variation & D/F & \multicolumn{1}{|c|}{ S.S. } & \multicolumn{1}{c}{ M.S. } & \multicolumn{1}{c}{ F } \\
\cline { 2 - 2 } Sex & 2 & $6,256.37$ & $3,128.18$ & \multirow{2}{*}{5.361} \\
Error & 262 & $152,631.09$ & 582.56 & \\
Total & 264 & $158,887.46$ & & \\
\hline
\end{tabular}

1 Significant at 1-percent level

Duncan Multiple Test at 1-percent level

At 5-percent level

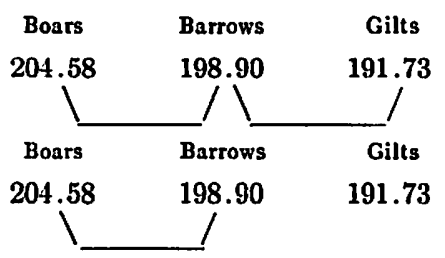

It is well known that management, in particular the feeding aspects of it, could greatly affect the growth rate of the pigs from weaning to 154 days of age, or at any other time, as far as that is concerned. Therefore, it is convenient to keep in mind that these correlation coefficients were obtained in animals that were kept under the same management practices year after year.

As far as sex differences in weight at the various periods are concerned, the only period during which the sex was responsible for differences was in the weight at 154 days of age. This is contrary to other studies made in which the boars were always heavier at all periods than the barrows or the gilts; in this case this was true only at the market time, 154 days of age.

In general, the correlation coefficients found in this study tend to show that the heavier pigs at each weight period tend to remain so during all their lives, as long as the management is kept constant throughout. 


\section{SUMMARY}

The correlation coefficients between the various successive weight periods were obtained from data on the $3 / 4$ Duroc $\times 1 / 4$ English Large Black Liandrace line of pigs of the University of Puerto Rico's Agricultural Experiment Station, Mayagüez Campus. These periods were at birth, at 21 days, at weaning time, and at 154 days of age. The data of 41 boars, 86 barrows, and 138 gilts covering the period from the fall of 1961 to the fall of 1965 were included.

All the correlation coefficients found were positive and significant, with the exception of birth to weaning, and to 154 days, and 21 days to 154 days of age in the boars. Those between the weaning weight and at 154 days of age were on the order of over +0.60 for all sexes. This fact was. further confirmed by the logistic equation used with the same data and included here.

Even though the boars were heavier than the barrows in all the weight periods, and these, in order, to the gilts, only at birth and at 154 days of age, there was a significant difference in favor of boars and barrows as compared with gilts.

\section{RESUMEN}

Se determinaron los coeficientes de correlación en los diferentes períodos de pesaje de los animales de la línea de cerdos 3/4 Duroc $\times 1 / 4$ English Large Black Landrace, desarrollada por la Estación Experimental Agrícola de la Universidad de Puerto Rico, Recinto de Mayagüez. Los datos utilizados fueron: peso al nacer, peso a los 21 días, peso al destete ( 56 días) y peso a los 154 días de nacidos. La información se obtuvo de 41 verracos, 86 castrados y 138 hembras durante el período comprendido entre el otoño del 1961 y el otoño del 1965.

Se encontró que todas las correlaciones fueron positivas y significativas, excepto tres. Estas excepciones, en el caso de los verracos, fueron la correlación entre el peso al nacer y el peso al destete; entre el peso al nacer y a los 154 días; y entre el peso a los 21 días y a los 154 días. La correlación entre el peso al destete y a los 154 días de nacidos, tuvo el nível más alto en todos los sexos, esto es, sobre +0.60 . Estos datos también fueron confirmados cuando se hizo uso de la ecuación logística incluída en este trabajo.

En cada período de pesaje los verracos pesaron más que los castrados y éstos, a su vez, más que las hembras. Sin embargo, cuando se compararon los pesos de los animales al nacer y a los 154 días de nacidos, sblo hubo una diferencia significativa a favor de los verracos y de los castrados y en contra de las hembras. 